\title{
NUP98 wt Allele
}

National Cancer Institute

\section{Source}

National Cancer Institute. NUP98 wt Allele. NCI Thesaurus. Code C52289.

Human NUP98 wild-type allele is located in the vicinity of 11 p15.5 and is approximately $123 \mathrm{~kb}$ in length. This allele, which encodes nuclear pore complex protein Nup98-Nup96 protein, is involved in the regulation of the nuclear pore complex and protein docking. Translocations in several myeloid leukemias contain NUP98 fused to other genes; $t(7 ; 11)$ (p15;p15) generates N-terminal NUP98 fused in-frame to HOXA9. Alterations in this region have been associated with the Beckwith-Wiedemann syndrome, Wilms tumor, rhabdomyosarcoma, adrenocortical carcinoma, and lung, ovarian, and breast cancer. 